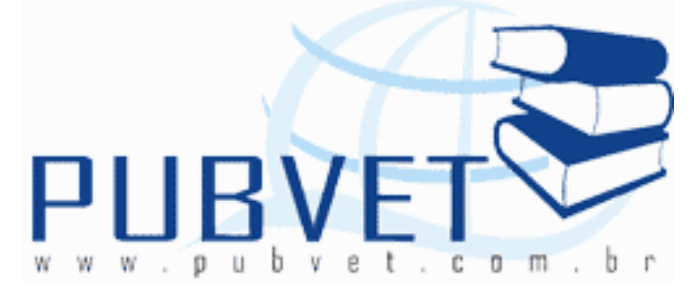

PUBVET, Publicações em Medicina Veterinária e Zootecnia.

\title{
Leites fermentados: histórico, composição, características físico- químicas, tecnologia de processamento e defeitos
}

\begin{abstract}
Carla da Silva Carneiro ${ }^{1 *}$; Fernanda Lima Cunha ${ }^{1}$; Lúcia Rosa de Carvalho²; Kênia de Fátima Carrijo ${ }^{3}$; Alexandre Borges ${ }^{1}$; Marco Antônio Sloboda Cortez ${ }^{4}$.
\end{abstract}

${ }^{1}$ Doutorandos do Programa de Pós Graduação em Higiene Veterinária e Processamento Tecnológico de Produtos de Origem Animal. Faculdade de Veterinária. Universidade Federal Fluminense (UFF). *Autor para contato: Carla da Silva Carneiro. Endereço: Rua Vital Brazil Filho, 64, Santa Rosa, CEP: 24.230-340. Niterói-RJ, Brasil. Email: carlavet.s@gmail.com

${ }^{2}$ Docente da Faculdade de Nutrição. Departamento de Nutrição Social. Universidade Federal Fluminense (UFF), Niterói-RJ, Brasil.

${ }^{3}$ Docente da Faculdade de Medicina Veterinária, Universidade Federal de Uberlândia (UFU), Uberlândia-MG, Brasil.

${ }^{5}$ Docente da Faculdade de Veterinária. Departamento de Tecnologia de Alimentos. Universidade Federal Fluminense (UFF), Niterói-RJ, Brasil.

\section{Resumo}

Leite fermentado é o nome genérico dado a produtos como: iogurte, leite cultivado, leite acidófilo, kefir, kumys e coalhada. Este nome se deve ao fato do leite ser inoculado com culturas iniciadoras de microrganismos ácido-láticos, que convertem parte da lactose do leite em ácido lático por meio da fermentação. A fermentação lática aumenta o prazo de validade do leite, 
CARNEIRO, C.S. et al. Leites fermentados: histórico, composição, características físicoquímicas, tecnologia de processamento e defeitos. PUBVET, Londrina, V. 6, N. 27, Ed. 214, Art. 1424, 2012.

inibindo o crescimento de bactérias patogênicas e/ou deteriorantes. Outras substâncias também são formadas no processo de fermentação, conferindo aos produtos características sensoriais desejáveis. Originalmente populares no Oriente Médio, os leites fermentados tiveram uma difusão mundial de seu consumo, principalmente a partir do desenvolvimento de produtos adicionados de ingredientes como frutas e aromatizantes. A relação destes produtos como alimentos funcionais, que visam benefícios à saúde, a simplicidade da tecnologia de fabricação, o preço acessível e o relativo elevado prazo de validade em relação ao leite, são alguns dos fatores responsáveis pelo sucesso destes produtos no mundo. Neste trabalho foi realizado um levantamento bibliográfico sobre o histórico, a importância, a composição, características físico-químicas, a fabricação e os defeitos que podem ocorrer nos leites fermentados, com ênfase no iogurte e kefir.

Palavras-chave: leites fermentados, fermentação lática, tecnologia de fabricação, alimentos funcionais.

\title{
Fermented milk: history, composition, physical and chemical properties, processing technology and defects
}

\begin{abstract}
Fermented milk is the generic name given to products such as yogurt, cultured milk, acidophilus milk, kefir, curd and kumys. This name is due to the fact that the milk is inoculated with starter cultures of lactic acid microorganisms, which convert part of the lactose from milk to lactic acid by fermentation. The lactic acid fermentation increases the shelf life of milk, inhibiting the growth of pathogenic bacteria and / or deteriorating. Other substances are also formed in the fermentation process, giving the products desirable sensory characteristics. Originally popular in the Middle East, fermented milks have a global spread of its consumption, mainly from the development of products containing added ingredients such as fruits and flavorings. The ratio of these products as functional foods aimed at health benefits, simplicity of manufacturing
\end{abstract}


CARNEIRO, C.S. et al. Leites fermentados: histórico, composição, características físicoquímicas, tecnologia de processamento e defeitos. PUBVET, Londrina, V. 6, N. 27, Ed. 214, Art. 1424, 2012.

technology, the affordable and high relative expiration date for milk are some of the factors responsible for the success of these products in the world. In this paper we present a literature on the history, importance, composition, physicochemical characteristics, manufacturing and defects that can occur in fermented milk products, with emphasis on yogurt and kefir.

Keywords: fermented milk, lactic acid fermentation, manufacturing technology, functional foods.

\section{INTRODUÇÃO}

Leite fermentado é o nome genérico dado a produtos como: iogurte, leite cultivado, leite acidófilo, kefir, kumys e coalhada. Este nome se deve ao fato do leite ser inoculado com culturas iniciadoras de microrganismos ácido-láticos, que convertem parte da lactose do leite em ácido lático por meio da fermentação. A fermentação lática aumenta o prazo de validade do leite, inibindo o crescimento de bactérias patogênicas e/ou deteriorantes. Outras substâncias como dióxido de carbono, ácido acético, diacetil e acetaldeído também são formadas no processo de fermentação, conferindo aos produtos características sensoriais desejáveis.

A produção e a comercialização destes leites são regulamentadas e devem seguir alguns padrões de qualidade e composição. Eles são ajustados em seu teor de gordura e de sólidos não gordurosos, e modificados pela inoculação de culturas lácteas. Atualmente, existe uma grande variedade de leites fermentados, classificados de diferentes maneiras.

Originalmente, a popularidade destes produtos estava restrita ao Oriente Médio e a região dos Bálcãs e das montanhas de Caucasus. Porém, os leites fermentados tiveram uma difusão mundial de seu consumo, principalmente a partir do desenvolvimento de produtos adicionados de ingredientes como frutas e aromatizantes. A relação destes produtos como alimentos funcionais, que visam benefícios à saúde, a simplicidade da tecnologia de fabricação, o 
CARNEIRO, C.S. et al. Leites fermentados: histórico, composição, características físicoquímicas, tecnologia de processamento e defeitos. PUBVET, Londrina, V. 6, N. 27, Ed. 214, Art. 1424, 2012.

preço acessível e o relativo elevado prazo de validade em relação ao leite, são alguns dos fatores responsáveis pelo sucesso destes produtos no mundo.

\section{REVISÃO BIBLIOGRÁFICA}

\subsection{HISTÓRICO DOS LEITES FERMENTADOS}

O leite fermentado é um alimento lácteo conhecido desde os primórdios da civilização, sendo classificados como os mais antigos derivados. Algumas referências sobre esse alimento são encontradas na bíblia: Abraão acreditava que sua longevidade estava relacionada ao consumo de leite fermentado. Moisés considerava o leite fermentado um presente de Deus, assim como o mel e o vinho. Cientistas conhecidos como Hipócrates, consideravam o leite fermentado não apenas um alimento, mas também um remédio, prescrevendo-o no tratamento de distúrbios estomacais e intestinais. $\mathrm{Na}$ França, o leite fermentado foi relacionado à cura de infecções intestinais e considerado um fator de auxílio à digestão (SACCARO, 2008).

No início do século 20, pesquisadores do instituto Pauster na França, começaram a apresentar explicações sobre os efeitos benéficos das bactérias acido láticas presentes no leite fermentado, sendo nesta época atribuída a ótima saúde e longevidade dos povos Búlgaros ao consumo elevado de leites fermentados. Em 1908, um pesquisador russo (Metchnikoff), do referido Instituto, ganhou o prêmio Nobel após isolar o Bacillus bulgaricus e analisar os efeitos benéficos desse microrganismo no leite fermentado. $O$ estudo foi baseado no fato de que as bactérias ácido-láticas, naturalmente presentes no intestino, apresentavam-se no leite e produziam substâncias que inibiam o crescimento de bactérias patogênicas e, assim prolongavam a longevidade dos consumidores. O Bacillus bulgaricus não produzia álcool no leite, diferente de outros alimentos lácteos amplamente consumidos na época, como kefir e Kumys. Metchnikoff acreditava que o crescimento de contaminantes 
CARNEIRO, C.S. et al. Leites fermentados: histórico, composição, características físicoquímicas, tecnologia de processamento e defeitos. PUBVET, Londrina, V. 6, N. 27, Ed. 214, Art. 1424, 2012.

bacterianos era inibido pelo ácido lático e outros produtos ainda não identificados, que atuavam sinergicamente no leite (ibid).

Originalmente o processo de fermentação envolvia a coagulação do leite por microrganismos presentes naturalmente no alimento, obtendo-se um produto final com características e propriedades físico-químicas diferentes da matéria original. Atualmente, o leite fermentado pode ser definido como um produto adicionado ou não de microrganismos específicos, responsáveis pela coagulação e acidificação do leite (PIARD et al., 1997).

Pode se afirmar que o início do século passado foi importante para a produção em grande escala dos leites fermentados. Em 1971, Isaac Carasso começou a produzir industrialmente o leite fermentado em Barcelona; esse foi o marco para o consumo em massa deste alimento (SACCARO, 2008).

\subsection{DEFINIÇÃO DE LEITES FERMENTADOS}

De acordo com a Instrução Normativa no 46 do Ministério da Agricultura Pecuária e Abastecimento (MAPA) (BRASIL, 2007) que trata do Regulamento Técnico de Identidade e Qualidade de Leites Fermentados, "entende-se por Leites Fermentados os produtos adicionados ou não de outras substâncias alimentícias, obtidas por coagulação e diminuição do $\mathrm{pH}$ do leite, ou reconstituído, adicionado ou não de outros produtos lácteos, por fermentação láctica mediante ação de cultivos de microrganismos específicos. Estes microrganismos específicos devem ser viáveis, ativos e abundantes no produto final durante seu prazo de validade".

\subsubsection{Iogurte, Yogur ou Yoghurt}

Entende-se por iogurte, yogur ou yoghurt o produto incluído na definição anterior, cuja fermentação se realiza com cultivos protossimbióticos de Streptococcus salivarius subsp. thermophilus e Lactobacillus delbrueckii subsp. 
CARNEIRO, C.S. et al. Leites fermentados: histórico, composição, características físicoquímicas, tecnologia de processamento e defeitos. PUBVET, Londrina, V. 6, N. 27, Ed. 214, Art. 1424, 2012.

Bulgaricus, aos quais se podem acompanhar, de forma complementar, outras bactérias ácido-lácticas que, por sua atividade, contribuem para a determinação das características do produto final (BRASIL, 2007).

\subsubsection{Leite fermentado ou cultivado}

O leite fermentado ou cultivado é o leite incluído na definição de Leites Fermentados, cuja fermentação se realiza com um ou vários dos seguintes cultivos: Lactobacillus acidophilus, Lactobacillus casei, Bifidobacterium sp, Streptococus salivarius subsp thermophilus e/ou outras bactérias acido-lácticas que, por sua atividade, contribuem para a determinação das características do produto final (BRASIL, 2007).

\subsubsection{Leite acidófilo ou acidofilado}

Entende-se por leite acidófilo ou acidofilado o produto incluído na definição de leite fermentado ou cultivado, cuja fermentação se realiza-se exclusivamente com cultivos de Lactobacillus acidophilus (BRASIL, 2007).

\subsubsection{Kefir}

Kefir é o produto incluído na definição 2.2 (de Leites Fermentados), cuja fermentação se realiza com cultivos acido-lácticos elaborados com grãos de Kefir, Lactobacillus kefir, espécies dos gêneros Leuconostoc, Lactococcus e Acetobacter com produção de ácido láctico, etanol e dióxido de carbono. Os grãos de Kefir são constituídos por leveduras fermentadoras de lactose (Kluyveromyces marxianus) e leveduras não fermentadoras de lactose (Saccharomyces omnisporus, Saccharomyces cerevisae e Saccharomyces exiguus), Lactobacillus casei, Bifidobaterium sp e Streptococcus salivarius subsp thermophilus (BRASIL, 2007). 
CARNEIRO, C.S. et al. Leites fermentados: histórico, composição, características físicoquímicas, tecnologia de processamento e defeitos. PUBVET, Londrina, V. 6, N. 27, Ed. 214, Art. 1424, 2012.

\subsubsection{Kumys}

Kumys o produto que também está incluído na primeira definição de Leites Fermentados (item 2.2), cuja fermentação se realiza com cultivos de Lactobacillus delbrueckii subsp. bulgaricus e Kluyveromyces marxianus (BRASIL, 2007).

\subsubsection{Coalhada ou Cuajada}

Coalhada ou Cuajada é o produto também incluído na definição 2.2, cuja fermentação se realiza por cultivos individuais ou mistos de bactérias mesofílicas produtoras de ácido láctico (BRASIL, 2007).

\subsection{CLASSIFICAÇÃO DOS LEITES FERMENTADOS SEGUNDO A LEGISLAÇÃO}

\subsubsection{Conteúdo de matéria gorda}

De acordo com o conteúdo de matéria gorda, os leites fermentados se classificam em:

a) Com creme: aqueles cuja base láctea tenha um conteúdo de matéria gorda mínima de $6,0 \mathrm{~g} / 100 \mathrm{~g}$.

b) Integrais ou Enteros: aqueles cuja base láctea tenha um conteúdo de matéria gorda mínima de $3,0 \mathrm{~g} / 100 \mathrm{~g}$.

c) Parcialmente desnatados: aqueles cuja base Láctea tenha um conteúdo de matéria gorda máxima de $2,9 \mathrm{~g} / 100 \mathrm{~g}$.

d) Desnatados: aqueles cuja base láctea tenha um conteúdo de matéria gorda máxima de $0,5 \mathrm{~g} / 100 \mathrm{~g}$. 
CARNEIRO, C.S. et al. Leites fermentados: histórico, composição, características físicoquímicas, tecnologia de processamento e defeitos. PUBVET, Londrina, V. 6, N. 27, Ed. 214, Art. 1424, 2012.

\subsubsection{Adição de ingredientes (Leites fermentados com adições)}

Quando em sua elaboração tenham sido adicionados ingredientes opcionais não lácteos, antes, durante ou depois da fermentação, até um máximo de $30 \% \mathrm{~m} / \mathrm{m}$, classificam-se como leites fermentados com adições.

No caso em que os ingredientes opcionais sejam exclusivamente açúcares, acompanhados ou não de glicídios (exceto polissacarídeos e polialcoóis) e/ou amidos ou amidos modificados e/ou maltodextrina e/ou se adicionam substâncias aromatizantes/saborizantes, classificam-se como leites fermentados com açúcar, açucarados ou adoçados e/ou aromatizados/saborizados (BRASIL, 2007).

\subsection{COMPOSIÇÃO E REQUISITOS}

\subsubsection{Ingredientes obrigatórios}

São obrigatórios na composição dos leites fermentados: leite e/ou leite reconstituído em seu conteúdo de gordura; cultivo de bactérias lácticas e/ou cultivo de bactérias lácticas específicas, correspondendo ao produto desejado (BRASIL, 2007).

\subsubsection{Ingredientes opcionais}

São opcionais: o leite concentrado, creme, manteiga, gordura anidra de leite "butteroil", leite em pó, caseinatos alimentícios, proteínas lácteas, outros sólidos de origem láctea, soros lácteos, concentrados de soros lácteos; frutas em forma de pedaços, polpa(s), suco(s) e outros preparados à base de frutas, maltodextrinas, outras substâncias alimentícias tais como: mel, coco, cereais, vegetais, frutas secas, chocolate, especiarias, café, outras, sós ou combinadas;

açúcares e/ou glicídios (exceto polialcoóis e polissacarídeos); cultivos de bactérias lácticas subsidiárias; amidos ou amidos modificados em uma 
CARNEIRO, C.S. et al. Leites fermentados: histórico, composição, características físicoquímicas, tecnologia de processamento e defeitos. PUBVET, Londrina, V. 6, N. 27, Ed. 214, Art. 1424, 2012.

proporção máxima de $1 \%(\mathrm{~m} / \mathrm{m})$ do produto final. Os ingredientes opcionais não lácteos, sós ou combinados deverão estar presentes em uma proporção máxima de $30 \%(\mathrm{~m} / \mathrm{m})$ no produto final (BRASIL, 2007).

\subsubsection{Características sensoriais}

Com relação ao aspecto, os leites fermentados devem possuir a consistência firme, pastosa, semisólida ou líquida. A coloração deve ser branca, ou ainda, pode variar de acordo com de acordo com as substâncias alimentícias e/ou corantes adicionados. O odor e o sabor são característicos ou também de acordo com as substâncias alimentícias e/ou substâncias aromatizantes/saborizantes adicionadas (BRASIL, 2007).

\subsubsection{Características físico-químicas}

Os leites fermentados deverão possuir as características físico-químicas observadas na tabela 1.

Tabela 1. Características físico-químicas dos leites fermentados

\begin{tabular}{lccc}
\multicolumn{1}{c}{ Produto } & $\begin{array}{c}\text { Matéria Gorda } \\
\text { Láctea }\end{array}$ & $\begin{array}{c}\text { Acidez } \\
(\mathbf{g} \text { ác. }\end{array}$ & $\begin{array}{c}\text { Proteínas } \\
\text { Lácteas }\end{array}$ \\
\hline Com creme & Mín. 6,0 & 0,6 a 2,0 & Mín. 2,9 \\
Integral & 3,0 a 5,9 & 0,6 a 2,0 & Mín. 2,9 \\
Parcialmente desnatado & 0,6 a 2,9 & 0,6 a 2,0 & Mín. 2,9 \\
Desnatado & Máx. 0,5 & 0,6 a 2,0 & Mín. 2,9 \\
\hline
\end{tabular}

Fonte: (Brasil, 2007) * Os leites fermentados com agregados, açucarados e/ou saborizados poderão ter conteúdo de matéria gorda e proteínas inferiores, não devendo reduzir-se a uma proporção maior do que a porcentagem de substâncias alimentícias não lácteas, açúcares acompanhados de glicídios (exceto polissacarídeos e polialcoóis) e/ou amidos modificados e/ou maltdextrina e/ou aromatizante / saborizante adicionados. 
CARNEIRO, C.S. et al. Leites fermentados: histórico, composição, características físicoquímicas, tecnologia de processamento e defeitos. PUBVET, Londrina, V. 6, N. 27, Ed. 214, Art. 1424, 2012.

Ainda segundo a IN n46 do MAPA, considerando as características físicoquímicas, os leites fermentados devem seguir, em particular, os requisitos apresentados na tabela 2 .

Tabela 2. Características físico-químicas específicas dos diferentes leites fermentados

\begin{tabular}{|c|c|c|}
\hline Produto & $\begin{array}{c}\text { Acidez } \\
\text { (g de ác. Lático/100g) }\end{array}$ & $\begin{array}{l}\text { Etanol } \\
(\% \mathrm{o} / \mathrm{m})\end{array}$ \\
\hline Iogurte & 0,6 a 1,5 & - \\
\hline Leite fermentado ou cultivado & 0,6 a 2,0 & - \\
\hline Leite acidófilo ou acidofilado & 0,6 a 2,0 & - \\
\hline Kefir & $<1,0$ & 0,5 a 1,5 \\
\hline Kumys & $>0,7$ & Mín. 0,5 \\
\hline Coalhada & 0,6 a 2,0 & - \\
\hline
\end{tabular}

Fonte: (Brasil, 2007)

\subsubsection{Características microbiológicas ou contagem de microrganismos específicos}

São apresentadas na tabela 3, as características microbiológicas que os leites fermentados deverão apresentar durante seu prazo de validade comercial. 
CARNEIRO, C.S. et al. Leites fermentados: histórico, composição, características físicoquímicas, tecnologia de processamento e defeitos. PUBVET, Londrina, V. 6, N. 27, Ed. 214, Art. 1424, 2012.

Tabela 3. Contagem de microrganismos específicos

\begin{tabular}{|c|c|c|}
\hline Produto & $\begin{array}{c}\text { Contagem de bactérias } \\
\text { lácticas (UFC/g) }\end{array}$ & $\begin{array}{c}\text { Contagem de } \\
\text { leveduras } \\
\text { específicas } \\
(\mathrm{UFC} / \mathrm{g})\end{array}$ \\
\hline Iogurte & Mín. $10^{7 *}$ & $\overline{-}$ \\
\hline Leite fermentado ou cultivado & Mín. $10^{6 *}$ & - \\
\hline Leite acidófilo ou acidofilado & Mín. $10^{7}$ & - \\
\hline Kefir & Mín. $10^{7}$ & Mín. $10^{4}$ \\
\hline Kumys & Mín. $10^{7}$ & Mín. $10^{4}$ \\
\hline Coalhada & Mín. $10^{6}$ & - \\
\hline
\end{tabular}

Fonte: (Brasil, 2007)* No caso em que se mencione o uso de bifidobactérias, a contagem será de no mínimo $10^{6}$ UFC de Bifidobactérias $/ \mathrm{g}$.

\subsubsection{Tratamento térmico, condições de comercialização e acondicionamento}

Os leites fermentados não deverão ter sido submetidos a qualquer tipo de tratamento térmico após a fermentação, pois o objetivo é que os microrganismos dos cultivos utilizados permaneçam viáveis, ativos e em concentração igual ou superior à definida pela legislação (no produto final e durante seu prazo de validade). A temperatura de conservação e comercialização não deve ser superior a $10^{\circ} \mathrm{C}$ e, estes produtos devem ser envasados com materiais adequados que não sofram alterações a esta temperatura, de forma a conferir ao produto uma proteção adequada. 
CARNEIRO, C.S. et al. Leites fermentados: histórico, composição, características físicoquímicas, tecnologia de processamento e defeitos. PUBVET, Londrina, V. 6, N. 27, Ed. 214, Art. 1424, 2012.

\subsection{IOGURTE}

\subsubsection{Definição de iogurte}

Conforme comentado anteriormente, o iogurte é o produto obtido pela fermentação do leite tradicionalmente pelos microrganismos Streptococcus thermophilus e Lactobacillus delbrueckii ssp bulgaricus, e é caracterizado por consistir em um gel suave, viscoso com delicado sabor característico. 0 crescimento destes microrganismos ocorre de forma simbiótica. O fato de ser considerado um alimento de alto valor nutritivo, associado à possibilidade de fabricação com diferentes teores de gordura, com adição de frutas, mel e cereais é, sem dúvida, um fator que favorece a expansão do mercado deste produto (LIMA, 2009).

\subsubsection{Histórico do iogurte}

Ninguém sabe a origem ao certo do iogurte. Durante muito tempo diversas civilizações tem conhecimento dos seus efeitos benéficos sobre a saúde e nutrição humana. O iogurte provavelmente é originário do Oriente Médio. A evolução do produto fermentado ao longo dos anos pode ser atribuída às habilidades culinárias dos povos nômades desta parte do mundo (TAMIME; ROBINSON, 1991).

Segundo Neves (1993), os precursores do iogurte estão entre os mais antigos subprodutos do leite. Conta à lenda que o patriarca Abrahão convidou os três anjos que Ihe apareceram em Hebrón para tomar leite azedo, precursor do iogurte, pois ele atribuía longevidade e vigor a esse alimento. Antigos textos egípcios e hindus o mencionam como verdadeiro alimento dos deuses. Outras lendas atribuem que sua receita foi trazida aos homens por anjos. $O$ iogurte, como é conhecido hoje, apareceu na Europa nos meados do século 16, proveniente do Império Otomano. Nessa época, acreditava-se que a força e coragem de Gengis Khan vinham de sua alimentação à base de carne crua e 
CARNEIRO, C.S. et al. Leites fermentados: histórico, composição, características físicoquímicas, tecnologia de processamento e defeitos. PUBVET, Londrina, V. 6, N. 27, Ed. 214, Art. 1424, 2012.

iogurte. Vale a menção que o imperador Francisco I, da França (1494-1547) chamava-o pelo sugestivo apelido de leite da vida eterna.

Pelo mundo, as matérias-primas habituais para o iogurte são o leite de vaca, o de cabra e o de ovelha, mas existem versões mais incomuns como o de búfala e até de égua, rena e de camela (ibid).

Um grande admirador do iogurte foi o líder indiano Mahatma Gandhi que incentivou o consumo de iogurte entre o seu povo. Chama atenção entre os textos deixados por ele, denominado Reforma alimentar, que contém um capítulo dedicado ao leite com ênfase ao iogurte. Uma curiosidade sobre o iogurte indiano é que ele é produzido a partir de leite desnatado, proporcionando um produto menos gorduroso (ibid).

\subsubsection{Classificação do iogurte quanto ao teor de gordura}

Em termos de composição química, o iogurte é universalmente classificado em três tipos com base no seu conteúdo de gordura:

a) Integral: mínimo de 3\% de gordura;

b) Parcialmente desnatado: de 0,6 a 2,9\%;

C) Desnatado: menos de 0,5\% de gordura.

\subsubsection{Classificação do iogurte quanto à estrutura física do coágulo}

Outra classificação bastante utilizada refere-se à estrutura física do coágulo, podendo este ser firme (tradicional), batido ou líquido (ABREU, 1999).

a) Iogurte firme (tradicional): caracteriza-se pela fermentação já dentro da embalagem. Como ele não sofre homogeneização após a sua fermentação, ele se apresenta na forma de uma coalhada firme e mais ou menos consistente. Este tipo de iogurte pode ser comercializado na sua forma natural (sem adição de açúcar e sabores), na forma aromatizada (com adição de açúcar, sabores, aromas e corantes) ou tipo "sundae" (uma camada de polpa de fruta, mel, etc. no fundo da embalagem, ficando o iogurte sobre esta). 
CARNEIRO, C.S. et al. Leites fermentados: histórico, composição, características físicoquímicas, tecnologia de processamento e defeitos. PUBVET, Londrina, V. 6, N. 27, Ed. 214, Art. 1424, 2012.

b) Iogurte batido: o leite é colocado em um tanque (com ou sem adição de açúcar, aromatizante, sabores e corantes) e depois de completa a fermentação, o iogurte é batido e posteriormente embalado.

c) Iogurte líquido: também conhecido como "iogurte para beber". Seu consumo vem aumentando consideravelmente nos últimos tempos, podendo também ser consumido de forma natural ou adicionado de açúcar, aromatizante, sabores e corantes. Normalmente, é comercializado em embalagens plásticas, tipo garrafas e em embalagens tipo "Longa Vida", sendo sua fermentação conduzida em tanques.

\subsubsection{Características do iogurte}

\subsubsection{Nutricionais}

Segundo Botazzi (1994), a lactose particularmente transformada em ácido láctico, durante o percurso da fermentação, facilitou a assimilação do iogurte em indivíduos com intolerância à lactose, os quais tem problemas em assimilar os nutrientes do leite.

A acidez do iogurte confere uma proteção natural contra infecções, manifestando-se na inibição de diferentes bactérias patogênicas no iogurte, o acido láctico dissolve o cálcio presente no iogurte favorecendo a sua assimilação. As proteínas do leite que tem um alto valor biológico são parcialmente digeridas por uma ação das bactérias permitindo uma melhor digestão. As vitaminas do leite ajudam no desenvolvimento das bactérias lácticas que, por sua vez, produzem outras vitaminas, aumentando assim a variedade de vitaminas presentes no iogurte que apresenta uma ampla variedade de minerais, destacando-se com maior importância o cálcio, que para além do mais apresenta uma elevada biodisponibilidade (ibid). 
CARNEIRO, C.S. et al. Leites fermentados: histórico, composição, características físicoquímicas, tecnologia de processamento e defeitos. PUBVET, Londrina, V. 6, N. 27, Ed. 214, Art. 1424, 2012.

\subsubsection{Microbiológicas}

Durante seu período de validade a contagem de bactérias ácido-lácticas totais deve ser de no mínimo $10^{7} \mathrm{UFC} / \mathrm{g}$ (conforme exposto na tabela 3 ). Os dois microrganismos obrigatórios para se conseguir um iogurte são: Streptococcus thermophillus e Lactobacillus deubrueckii ssp. bulgaricus. Outros microrganismos como Lactobacillus acidophillus também podem estar presentes.

a) Streptococcus salivarus ssp., thermophillus

- Cresce primeiro, rapidamente até pH 5,5 (menos tolerante à acidez, até \pm $\left.80^{\circ} \mathrm{D}\right)$;

- Produz compostos utilizados pelo L. bulgaricus;

- Produz ácido fórmico, estimula o L. bulgaricus;

- Consome oxigênio, diminui o potencial de óxido-redução, bom para o $L$. bulgaricus

b) L.. bulgaricus

- Mais tolerante à acidez;

- Produz compostos aromáticos;

- Proteolítico, libera valina, glicina e histidina: fatores de crescimento do Streptococcus salivarus ssp., thermophillus.

c) Crescimento conjugado

Streptococcus salivarus ssp., thermophillus cresce primeiro, atinge um máximo em torno de duas horas (obtendo uma relação de 3 a 4:1). Com o meio propício, $L$. bulgaricus inicia o crescimento atingindo um máximo em torno de 3,5 horas, quando a relação final volta a ser 1:1. 
CARNEIRO, C.S. et al. Leites fermentados: histórico, composição, características físicoquímicas, tecnologia de processamento e defeitos. PUBVET, Londrina, V. 6, N. 27, Ed. 214, Art. 1424, 2012.

\subsubsection{Físico-químicas}

Como exposto na tabela 2 a acidez do iogurte em gramas de ácido láctico por $100 \mathrm{~g}$ deve estar entre 0,6 e 1,5.

\subsubsection{Fluxograma de elaboração e descrição do processo de fabricação do iogurte}

Para obtenção de um produto de qualidade, com sabor, aroma, consistência e aparência característicos, tanto a composição do leite ou da mistura básica, como o processo de fabricação e a escolha e manuseio da cultura devem ser cuidadosamente controlados (SENAI, 1999). 
CARNEIRO, C.S. et al. Leites fermentados: histórico, composição, características físicoquímicas, tecnologia de processamento e defeitos. PUBVET, Londrina, V. 6, N. 27, Ed. 214, Art. 1424, 2012.

PRODUÇÃO DE IOGURTE COM POLPA FLUXOGRAMA DO PROCESSO (Adaptado de ORDOÑEZ, 2005).

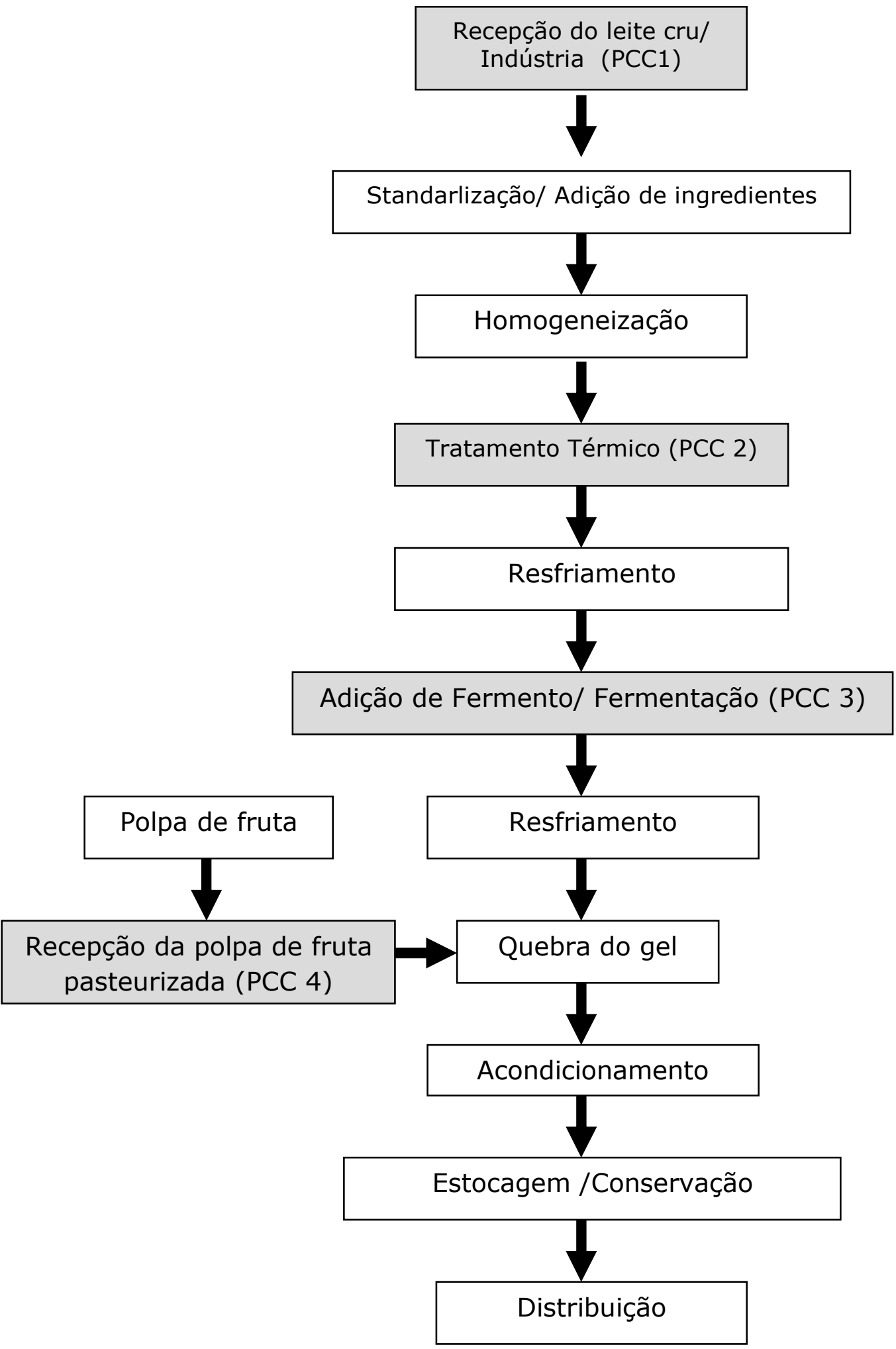


CARNEIRO, C.S. et al. Leites fermentados: histórico, composição, características físicoquímicas, tecnologia de processamento e defeitos. PUBVET, Londrina, V. 6, N. 27, Ed. 214, Art. 1424, 2012.

\subsubsection{Descrição do processo de fabricação do iogurte}

Recepção do leite cru / Indústria: o leite cru é transportado em caminhão-tanque em temperatura de até $7^{\circ} \mathrm{C}$ e deverá estar com acidez máxima de $18^{\circ} \mathrm{D}$ e isento de qualquer tipo de fraude (SENAI, 1999). Esta fase pode ser considerada como um Ponto Crítico de Controle na fabricação dos leites fermentados. O leite deverá ser de boa qualidade físico-química e microbiológica (acidez entre $15-18^{\circ} \mathrm{D}$ e ausente de patógenos). Não deverá ter a presença de antimicrobianos, bacteriófagos, produtos de limpeza ou qualquer outro componente que possa afetar a fermentação do produto (TETRAPAK, 1995).

Standarlização: Esta fase visa incrementar a concentração de sólidos para se obter propriedades reológicas desejadas no iogurte. O objetivo principal é aumentar a quantidade de sólidos lácteos não-gordurosos e a porcentagem de proteína, melhorando a consistência e viscosidade do iogurte pelo aumento de sólidos e padronização da quantidade de gordura do leite (ORDOÑEZ, 2005). Os métodos mais utilizados nesta etapa são: adição de leite em pó, concentração mediante evaporação a vácuo, concentração mediante filtração por membranas. Normalmente a adição de leite em pó desnatado é feita numa proporção de $3 \%$ para correção dos sólidos não gordurosos (SENAI, 1991). No produto comum, iogurte batido, a percentagem de sólidos não gordurosos deve estar na faixa de 8,5-10\%, enquanto que no produto tradicional o ESD deverá ser de aproximadamente $12 \%$.

Adição de ingredientes: edulcorantes e estabilizantes podem ser utilizados na produção de iogurtes. A sacarose ou a glicose podem ser adicionadas ao leite em conjunto com a adição de frutas. Também são utilizados estabilizantes e espessantes para aumentar a viscosidade do produto final e auxiliar na prevenção da separação do soro. Os estabilizantes mais usados são agar-ágar, pectina, goma guar, carragena e gelatina na proporção de $0,1 \%$ a $0,5 \%$. 
CARNEIRO, C.S. et al. Leites fermentados: histórico, composição, características físicoquímicas, tecnologia de processamento e defeitos. PUBVET, Londrina, V. 6, N. 27, Ed. 214, Art. 1424, 2012.

Homogeneização: Este processo tem como finalidade promover a dispersão homogênea dos constituintes da mistura-base de iogurte, aumentar a viscosidade e estabilidade além de melhorar a qualidade sensorial do produto. A viscosidade também dependerá da pressão da homogeneização e da temperatura. A melhor temperatura está entre 50-60. Após a homogeneização a mistura vai para o pasteurizador.

Tratamento Térmico (PCC): Nesta etapa ocorre a destruição da microbiota patogênica não esporulada, além disso, a redução da carga microbiana garante que o fermento adicionado encontre bastante substrato livre de competidores, o que proporciona um crescimento rápido. Ocorre a destruição de enzimas endógenas do leite (enzimas inibidoras naturais do leite). Ocorre desnaturação de proteínas, levando a interação da $\beta$ lactoglobulina com a k-caseína. Esta interação irá promover um aumento da capacidade de retenção de água pelas proteínas e uma maior firmeza do coágulo. Reduz a quantidade de oxigênio dissolvido, criando condições de microaerofilia favoráveis para o crescimento do cultivo iniciador. Ocorre a liberação de aminoácidos passíveis de estimular o crescimento dos microrganismos iniciadores (ORDOÑEZ, 2005). A pasteurização é realizada nos próprios tanques maturadores $\left(80^{\circ} \mathrm{C}\right.$ por 30 minutos), em pasteurizadores a placas ( 90 a $95^{\circ} \mathrm{C}$ por 3 minutos) ou em sistemas UHT (130 a $140^{\circ} \mathrm{C}$ por 15 30 segundos).

Resfriamento para adição do fermento: resfriamento até a temperatura de inoculação, dependente da cultura lática a ser utilizada (37 até $42-43^{\circ} \mathrm{C}$ ) para a atuação do fermento lácteo, esta temperatura é mantida até a coagulação. A mistura segue daí para os tanques de fermentação (SENAI, 1991).

Adição de Fermento / Fermentação (PCC): Dentro dos tanques de fermentação ocorrerá a adição do fermento. Nesta etapa o iogurte adquire a acidez, a consistência e o sabor característicos. Adição de fermento: adição de 1 a $2 \%$ de fermento lático em relação ao volume da mistura (SENAI, 1991). 0 cultivo iniciador não deve apenas fornecer uma quantidade abundante de 
CARNEIRO, C.S. et al. Leites fermentados: histórico, composição, características físicoquímicas, tecnologia de processamento e defeitos. PUBVET, Londrina, V. 6, N. 27, Ed. 214, Art. 1424, 2012.

microrganismos viáveis, mas deve proporcionar também uma população em equilíbrio com o número de indivíduos das espécies que intervêm na fermentação (Streptococcus thermophilos e Lactobacilus delbrueckii subsp. bulgaricus). Pretende-se que a taxa inicial de microrganismos seja bastante elevada, da ordem de $10^{7} \mathrm{UFC} / \mathrm{mL}$ para que a fermentação se produza com rapidez. Costuma-se incubar a temperatura de $42^{\circ} \mathrm{C}$, temperatura média entre a ótima das duas espécies responsáveis pela sua fermentação. A proporção inicial de ambas as espécies é de (1/1), modifica-se rapidamente após a semeadura. O Streptococcus thermophilos entra na fase de crescimento exponencial, devido a sua capacidade de se desenvolver em $\mathrm{pH}$ neutro iniciando a fermentação lática diminuindo $\circ \mathrm{pH}$ até 5,5 , enquanto que 0 Lactobacilus delbrueckii subsp. bulgaricus espera até que o ácido láctico se acumule para iniciar seu crescimento. A acidez, o consumo de oxigênio e a liberação de substâncias voláteis tais como o ácido fórmico e de substâncias aminadas derivadas das proteínas do soro, produzem condições ideais para o desenvolvimento do Lactobacillus bulgaricus. A atividade proteolítica, ou seja, a liberação de aminoácidos (valina, ácido glutâmico, triptofano e metionina) provocada pelos lactobacilos, estimula o crescimento dos cocos. Esta bactéria produz formiato durante o metabolismo da lactose e $\mathrm{CO}_{2}$ a partir da uréia presente no leite. Os dois metabólitos estimulam o crescimento do lactobacilo. Os principais produtos metabólicos dos microrganismos iniciadores são ácido láctico, acetaldeído e diacetil, principais produtores de aroma do iogurte (ORDOÑEZ, 2005). Durante todo o processo de fermentação deverão ser realizadas análises de acidez. Chegando a acidez desejada, deve-se resfriar o produto imediatamente; logo, a acidez deve estar em torno de 70 a $72^{\circ}$ Dornic e o $\mathrm{pH}$ em torno de 4,5 a 4,7 .

Resfriamento: Sua finalidade é frear a atividade do iniciador e suas enzimas para evitar que a fermentação prossiga. Recomenda-se que a temperatura final do iogurte não exceda $5^{\circ} \mathrm{C}$; desse modo, tem-se a coexistência de $\mathrm{pH}$ baixo e temperatura de refrigeração, que atuam em sinergia para manter o iogurte em um estado apropriado para o consumo por 
CARNEIRO, C.S. et al. Leites fermentados: histórico, composição, características físicoquímicas, tecnologia de processamento e defeitos. PUBVET, Londrina, V. 6, N. 27, Ed. 214, Art. 1424, 2012.

no mínimo 20 dias. O resfriamento muito rápido pode afetar a estrutura do coágulo, levando à separação do soro devido à intensa retração das proteínas do coágulo, que afeta a capacidade de retenção de água (ORDOÑEZ, 2005).

Quebra do gel: o processo de quebra do gel irá modificar a estrutura coloidal formada, levando a liberação do soro e a diminuição de viscosidade aparente. Após o resfriamento a $10^{\circ} \mathrm{C}$ o gel poderá ser quebrado, permitindo uma absorção melhor do soro pelas micelas de caseína evitando a sinérese. Esta fase é o momento ideal para ser adicionada a polpa de fruta pasteurizada, aroma e sabores dependendo do caso (PCC).

Acondicionamento: em recipientes invioláveis, opacos, resistentes. impermeáveis a sabores e odores estranhos, não deve incorporar corante, resistentes ao oxigênio, umidade, deverá manter acidez do produto. Embalagens mais comuns em copos ou frascos de polipropileno ou poliestireno.

Estocagem e conservação: O iogurte será estocado em câmaras frigoríficas $\mathrm{a} \pm 5^{\circ} \mathrm{C}$ e conservado a esta temperatura por até 15 dias mantendose suas características normais. Caso ocorra a elevação da temperatura, a acidez poderá aumentar chegando à $85-95^{\circ} \mathrm{D}$, o que é indesejável.

Distribuição: Em carros isotérmicos ou em caminhões frigoríficos.

\subsection{KEFIR}

\subsubsection{Definição}

Vale (2009) menciona o kefir como um alimento originário das regiões montanhosas do Cáucaso, entre o Mar Negro e o Mar Cáspio, sendo preparado há mais de quatro mil anos pelos povos dessa região, que costumam viver até os 120 anos de idade, com bastante vigor. Seus grãos são resultantes do agrupamento de alguns microrganismos em simbiose, como leveduras, bactérias acéticas e lactobacilos. 
CARNEIRO, C.S. et al. Leites fermentados: histórico, composição, características físicoquímicas, tecnologia de processamento e defeitos. PUBVET, Londrina, V. 6, N. 27, Ed. 214, Art. 1424, 2012.

É uma bebida láctea fermentada, ligeiramente efervescente e espumosa que difere do iogurte por ser mais líquida e por conter, além do ácido lático, álcool e gás carbônico. Este produto cuja fermentação se realiza com cultivos acidolácticos elaborados com grãos de Kefir, Lactobacillus kefir, espécies dos gêneros Leuconostoc, Lactococcus e Acetobacter. Os grãos de Kefir são constituídos por leveduras fermentadoras de lactose (Kluyveromyces marxianus) e leveduras não fermentadoras de lactose (Saccharomyces omnisporus e Saccharomyces cerevisae e Saccharomyces exiguus), Lactobacillus casei, Bifidobaterium sp e Streptococcus salivarius subsp thermophilus. Apresenta as seguintes características sensoriais: sabor levemente ácido, alcoólico, com formação de flavor típico de leveduras; ocorre produção de $\mathrm{CO}_{2}$ (SOUZA; GARCIA e VALLE 1984).

Duggan et al. (2003) afirmam que os benefícios do consumo de kefir são inúmeros, mas os principais são: incrementar o valor biológico das proteínas do leite; sintetizar ácido lático, o que diminui a intolerância a lactose e favorece a digestibilidade do leite mesmo para pessoas que sejam sensíveis ao leite de vaca; sintetizar vitaminas do complexo $B$; aumentar a resistência a infecções; ativar o sistema imunológico; restabelecer e equilibrar a flora intestinal; é regulador da flora intestinal, podendo ser usado tanto em casos de constipação quanto diarréia; diminui o risco de câncer, principalmente de cólon e diminui a fração do LDL do colesterol.

O kefir também fornece energia e diversas outras vantagens ao organismo de quem o ingere. Aumenta a imunidade, causa a regulação do fluxo intestinal e combate os diversos problemas, como acidez estomacal, distúrbios nervosos, disfunção hepática, reumatismo, colesterol alto, alergias, candidíase, asma, acne, problemas renais, problemas circulatórios, osteoporose, hepatite, bronquite, catarro, tuberculose, descontrole da produção de bilis, alergias, enxaqueca, males do cólon, úlceras, problemas digestivos, colites, bactérias hostis, prisão de ventre, diarréia, inflamações intestinais, ansiedade, depressão, diversos eczemas, auxilia na regulação da pressão sanguínea, melhora o sistema imunológico contra inúmeras doenças, 
CARNEIRO, C.S. et al. Leites fermentados: histórico, composição, características físicoquímicas, tecnologia de processamento e defeitos. PUBVET, Londrina, V. 6, N. 27, Ed. 214, Art. 1424, 2012.

regular o açúcar no sangue melhorando o diabetes, reduz o processo de envelhecimento e possui o Kefiran, tido como um anti-cancerígeno (OLIVEIRA et al. 2002).

\subsubsection{Histórico}

Os Grãos de Kefir foram considerados um presente de Alah entre os membros das tribos muçulmanas das Montanhas de Cáucaso. Kefir que é o leite cultivado com esta jóia probiótica foi respeitada com poderes curativos desde o início do décimo oitavo século (VECCHI; HAMSANANDA, S.D).

Foram passados Grãos de Kefir de geração para geração entre estas pessoas do Cáucaso. Estas pessoas consideraram Os Grãos de Kefir uma fonte de riqueza da família e da tribo (VECCHI; HAMSANANDA, S.D).

Nos início de 1900, dois irmãos de Blandovs que possuíram fábricas de queijo nas Montanhas do Norte do Cáucaso, foram contatados para ajudar a obter alguma cultura de Kefir para toda a Sociedade dos Médicos Russos. Os irmãos propuseram uma idéia para usar uma mulher jovem bonita de nome "Irina Sakharova", a persuadir um príncipe Caucasiano chamado "Bek-Mirza Barchorov" em doar para Irina um pouco de Grãos de Kefir. Irina deslumbrou o príncipe realmente com sua beleza, mas o príncipe recusou a the dar quaisquer destas Preciosas Jóias Vivas "probióticas", os Grãos de Kefir. O Príncipe não estava disposto a deixar Irina, e quando ela estava retornando para casa, ele organizou um sequestro com alguns dos seus homens. Contra a vontade dela, eles devolveram Irina para o tribunal onde o príncipe esperava ganhar o amor dela e propôs matrimônio. Mas Irina recusou. Blandovs para quem Irina trabalhou na fábrica fazendo queijos, apoiada pelos dois irmãos, levou o caso dela contra o príncipe para o tribunal do Tzar. O príncipe ofereceu ouro e jóias como reparação para os crimes feitos contra ela, mas ela recusou a oferta. Ao invés disso, como reparação exigiu Irina, e recebeu as Jóias Probióticas, que foram os grãos de Kefir (ibid). 
CARNEIRO, C.S. et al. Leites fermentados: histórico, composição, características físicoquímicas, tecnologia de processamento e defeitos. PUBVET, Londrina, V. 6, N. 27, Ed. 214, Art. 1424, 2012.

Em 1908, Irina Sakharova trouxe o primeiro Kefir para Moscou onde era medicinalmente usado com grande sucesso. Com 85 anos de idade, Irina em 1973 recebeu uma carta do Ministro da Indústria de Alimentos da URSS expressando seu reconhecimento e agradecendo seu papel primário trazendo Kefir para a população russa (ibid).

\subsubsection{Preparação do kefir}

O kefir pode ser preparado à base de leite de vaca ou de água. No país de origem, o kefir é preparado com leites de cabra, de ovelha, burra, vaca e égua. Segundo a natureza do leite empregado, obtém-se o kefir magro, semigordo e gordo sendo preferível o primeiro sempre que se pretende usar este produto para fins medicinais. Na Espanha, ou em outros países europeus, utiliza-se como matéria-prima exclusivamente o leite de vaca (ADOLFSSON, 2004).

\subsubsection{Características do Kefir}

\subsubsection{Nutricionais:}

Vale (2003), afirma que devido ás suas propriedades, o kefir é um alimento extremamente nutritivo, podendo revelar-se benéfico, pois aumenta o valor biológico das proteínas do leite. Ajuda ainda a sintetizar o acido láctico, reduzindo a lactase, favorecendo assim, a digestão do leite; propicia também a manutenção do equilíbrio da flora intestinal. Os alimentos probióticos podem ajudar a neutralizar os microrganismos patogênicos responsáveis pelas infecções. Os alimentos com estas características são ainda úteis em casos de colites, prisão de ventre e, segundo alguns nutricionistas, podem até ajudar a reduzir os riscos de câncer de cólon. Para além das qualidades referidas, desempenham um papel significativo no fortalecimento do sistema imunológico. 
CARNEIRO, C.S. et al. Leites fermentados: histórico, composição, características físicoquímicas, tecnologia de processamento e defeitos. PUBVET, Londrina, V. 6, N. 27, Ed. 214, Art. 1424, 2012.

O kefir é rico em ácido láctico, acético e glicônico, álcool etílico, gás carbônico, vitamina $B_{12}$ e polissacarídeos. O acido láctico é o principal metabólito formado durante o processo de fermentação do kefir e tal processo é capaz de converter de 20 a $50 \%$ da lactose em acido láctico, sendo que este é um conservante natural, o que faz o kefir ser um produto biologicamente seguro (SOUZA; GARCIA e VALLE, 1984).

Segundo o Instituto de Tecnologia de Alimentos (ITAL) de Campinas/SP, a composição do kefir está discriminada no quadro abaixo (Quadro 1):

Quadro 1. Composição do Kefir

\begin{tabular}{|c|c|}
\hline Componentes & Valores Aproximados \\
\hline ÁGUA & $87 \%$ \\
ACIDEZ EM GRAUS DORNIC (oD) & 80 (no final da incubação) \\
PROTEÍNAS TOTAIS & $3,4-4,2 \%$ \\
SACAROSE & 4,4 (mínimo) \\
GORDURA & $0,5-3,0 \%$ \\
MATÉRIAS ALBUMINÓIDES & $3,1 \%$ \\
PH & $4,2-4,5 \%$ \\
ACIDEZ VOLÁTIL & $2,8 \%$ \\
CASEÍNA & $0,2 \%$ \\
ALBUMINA & $2,6-3,75 \%$ \\
LACTOSE & $0,06 \%$ \\
PEPTONAS & $0,7 \%$ \\
ACIDO LÁTICO & $0 \mathrm{maOH} / 10 \times 100 \mathrm{ml}$ \\
ÁLCOOL & $0,23-1 \%$ \\
GÁS CARBÔNICO & $20-25 \%(\mathrm{v} / \mathrm{v})$ \\
MINERAIS & $0,74-0,8 \%$ \\
DIACETIL & $0,49 \mathrm{mg} / \mathrm{l}$ \\
ACETOALDEIDO & $1,30 \mathrm{mg} / \mathrm{l}$ \\
\hline
\end{tabular}

Fonte: Bol. ITAL, Campinas (1984). 
CARNEIRO, C.S. et al. Leites fermentados: histórico, composição, características físicoquímicas, tecnologia de processamento e defeitos. PUBVET, Londrina, V. 6, N. 27, Ed. 214, Art. 1424, 2012.

\subsubsection{Microbiológicas}

Frengova (2002) cita as principais bactérias e leveduras encontradas no kefir, descritas no quadro a seguir (Quadro 2).

Quadro 2. Principais microrganismos encontrados no Kefir

\begin{tabular}{|c|c|c|c|}
\hline Lactobacilos & $\begin{array}{c}\text { Estreptococos e } \\
\text { Lactococos }\end{array}$ & Leveduras & Acetobactérias \\
\hline Lb. acidophilus & Lactococci lactis subsp. & Candida kefir & Acetobacter aceti \\
\hline Lb. brevis & Lactis & C. pseudotropicalis & A. rasens \\
\hline Lb. casei & & C. rancens & \\
\hline Lb. casei subsp. & Lc. lactis var. diacetylactis & C. tenuis & \\
\hline rhamnosus & & Kluyveromyces & \\
\hline Lb. casei subsp. & Lc. lactis subsp. Cremoris & lactis & \\
\hline pseudoplantarum & & Kluyveromyces & \\
\hline Lb. paracasei subsp. & Streptococci salivarius & marxianus var. & \\
\hline paracasei & subsp. Thermophilus & marxianus & \\
\hline Lb. cellobiosus & & K. bulgaricus & \\
\hline Lb. delbrueckii subsp. & Strep. Lactis & K. fragilis / & \\
\hline bulgaricus & & marxianus & \\
\hline Lb. delbrueckii subsp. & Enterococcus & Saccharomyces & \\
\hline lactis & Durans & subsp. Torulopsis & \\
\hline Lb. fructivorans & & holmii & \\
\hline Lb. helveticus subsp. & Leuconostoc cremoris & Saccharomyces & \\
\hline lactis & & lactis & \\
\hline Lb. hilgardii & Leuc. mesenteroides & Sacc. & \\
\hline Lb. kefiri & & carlsbergensis & \\
\hline Lb. kefiranofaciens & & Sacc. unisporus & \\
\hline Lb. kefirgranum sp. no & & Debaryomyces & \\
\hline Lb. parakefir sp. nov & & hansenii & \\
\hline Lb. lactis & & Zygosaccharomyce & \\
\hline Lb. plantarum & & s rouxii & \\
\hline
\end{tabular}


CARNEIRO, C.S. et al. Leites fermentados: histórico, composição, características físicoquímicas, tecnologia de processamento e defeitos. PUBVET, Londrina, V. 6, N. 27, Ed. 214, Art. 1424, 2012.

No quadro 3 são citadas as bactérias iniciais usadas na fermentação láctea e algumas de suas propriedades (HELLER, 2001).

Quadro 3. Bactérias utilizadas na fermentação láctea e suas propriedades

\begin{tabular}{|c|c|c|c|c|c|c|c|}
\hline \multirow[b]{2}{*}{ Espécie } & \multicolumn{3}{|c|}{$\begin{array}{l}\text { Temperatura de } \\
\text { Crescimento }\end{array}$} & \multicolumn{2}{|c|}{$\begin{array}{l}\text { Fermentação } \\
\text { Acido Láctica }\end{array}$} & \multirow[b]{2}{*}{$\begin{array}{l}\text { Ac. } \\
\text { Lático }\end{array}$} & \multirow[b]{2}{*}{$\begin{array}{l}\text { pH } \\
\text { final }\end{array}$} \\
\hline & Mínimo & Ótimo & Maximo & $\begin{array}{c}\text { Homo } \\
F^{1}\end{array}$ & $\begin{array}{c}\text { Hetero } \\
\text { F }^{2}\end{array}$ & & \\
\hline $\begin{array}{l}\text { Lb. delbrueckii } \\
\text { subsp. bulgaricus }\end{array}$ & 22 & 45 & 52 & + & & $\begin{array}{l}1,5- \\
1,8\end{array}$ & 3,8 \\
\hline $\begin{array}{l}\text { Lb. delbrueckii } \\
\text { subsp. Lactis }\end{array}$ & 18 & 40 & 50 & + & & $\begin{array}{l}1,5- \\
1,8\end{array}$ & 3,8 \\
\hline Lb. helveticus & 22 & 42 & 54 & + & & $\begin{array}{l}1,5- \\
2,2\end{array}$ & 3,8 \\
\hline Lb. acidophilus & 27 & 37 & 48 & + & & $\begin{array}{l}0,3- \\
1,9\end{array}$ & 4,2 \\
\hline Lb. kefir & 8 & 32 & 43 & & + & $\begin{array}{l}1,2- \\
1,5\end{array}$ & - \\
\hline Lb. brevis & 8 & 30 & 42 & & + & $\begin{array}{l}1,2- \\
1,5\end{array}$ & - \\
\hline $\begin{array}{l}\text { Lb. casei subsp. } \\
\text { Casei }\end{array}$ & & 30 & & + & & $\begin{array}{l}1,2- \\
1,5\end{array}$ & - \\
\hline S. thermophilus & 22 & 40 & 52 & + & & $\begin{array}{l}0,6- \\
0,8\end{array}$ & 4,5 \\
\hline $\begin{array}{l}\text { Lc. lactis subsp. } \\
\text { lactis }\end{array}$ & 8 & 30 & 40 & + & & $\begin{array}{l}0,5- \\
0,7\end{array}$ & 4,6 \\
\hline $\begin{array}{l}\text { Lc. Lactis subsp } \\
\text { cremoris }\end{array}$ & 8 & 22 & 37 & + & & $\begin{array}{l}0,5- \\
0,7\end{array}$ & 4,6 \\
\hline $\begin{array}{l}\text { Lc. Lactis subsp } \\
\text { lactis biovar } \\
\text { diacetylactis }\end{array}$ & 8 & $22-28$ & 40 & + & & $\begin{array}{l}0,5- \\
0,7\end{array}$ & 4,6 \\
\hline
\end{tabular}


CARNEIRO, C.S. et al. Leites fermentados: histórico, composição, características físicoquímicas, tecnologia de processamento e defeitos. PUBVET, Londrina, V. 6, N. 27, Ed. 214, Art. 1424, 2012.

\begin{tabular}{|c|c|c|c|c|c|c|}
\hline $\begin{array}{l}\text { Ln. Mesenteroides } \\
\text { subsp cremoris }\end{array}$ & 4 & $20-28$ & 37 & + & $0,1-02$ & $\overline{5,6}$ \\
\hline $\begin{array}{l}\text { Ln. Mesenteroides } \\
\text { subsp dextranicum }\end{array}$ & 4 & $20-28$ & 37 & + & $\begin{array}{l}0,1- \\
0,2\end{array}$ & 5,6 \\
\hline $\begin{array}{l}\text { Bifidobacterium } \\
\text { (bifidum, infanctis, } \\
\text { etc.). }\end{array}$ & 22 & 37 & 48 & & $\begin{array}{l}0,1- \\
1,4\end{array}$ & 4,5 \\
\hline
\end{tabular}

Fonte: Heller (2001) ${ }^{1}$ Homo F: Homo-fermentativa; ${ }^{2}$ Hetero F: Heterofermentativa.

\subsubsection{Físico-químicas}

De acordo com Duggan (2002), os grãos vistos ao microscópio revelam uma estrutura complexa formada por:

- 4,4\% de lipídios;

- 12,1\% de cinzas;

- 45,7\% de mucopolissacarídeo;

$-34,3 \%$ de proteínas totais ( $27 \%$ insolúvel $1,6 \%$ solúvel e $5,6 \%$ aminoácidos livres);

- Vitaminas do complexo B;

- Vitamina K;

- Triptofano;

- Cálcio, fósforo e magnésio.

Os grãos de kefir são principalmente compostos de proteínas e polissacarídeos e uma microflora complexa que coexistem em uma associação simbiótica (SOUSA et al., 1984).

Frengova (2002), afirma que o kefir produz uma matriz de polissacarídeos que forma a estrutura dos grãos, o ácido lático, as leveduras e o polissacarídeo "kefiran" são descritos como uma comunidade simbiótica que concedem propriedades ao kefir.

A seguir será abordado o fluxograma de fabricação do kefir. 
CARNEIRO, C.S. et al. Leites fermentados: histórico, composição, características físicoquímicas, tecnologia de processamento e defeitos. PUBVET, Londrina, V. 6, N. 27, Ed. 214, Art. 1424, 2012.

\subsubsection{Fluxograma de fabricação do Kefir}

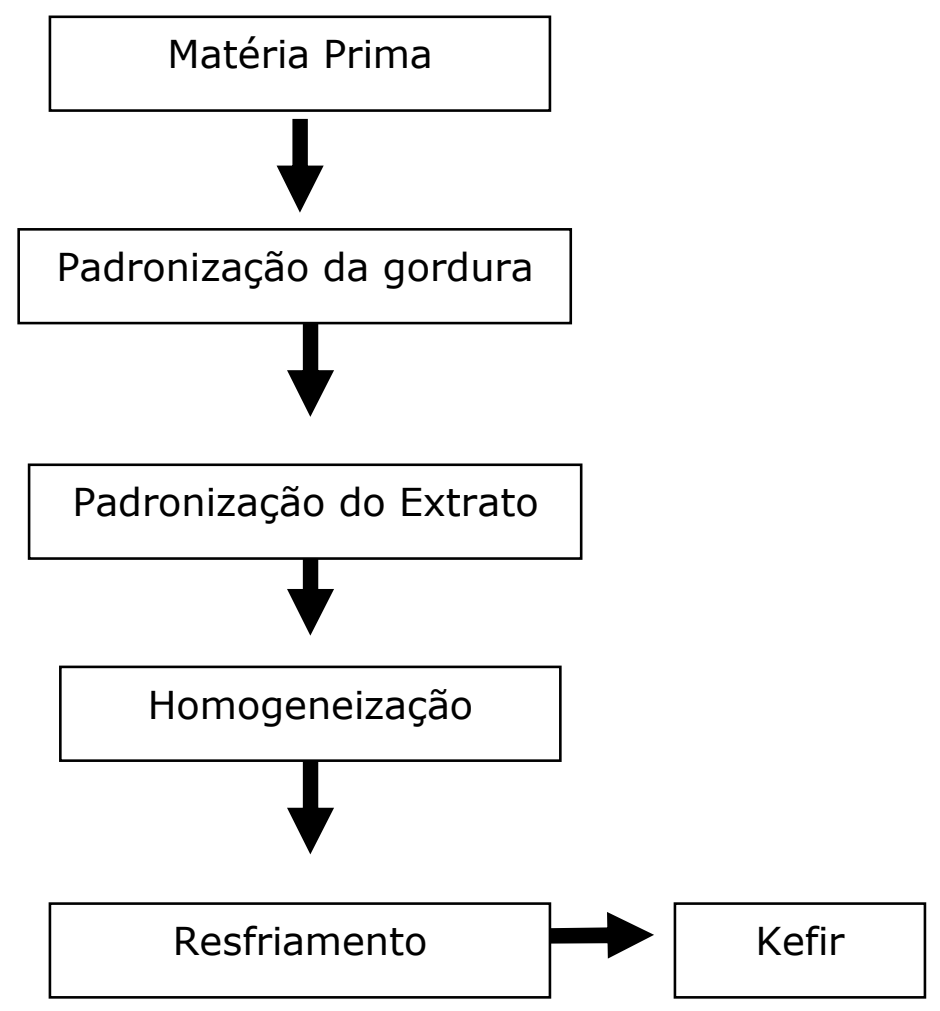

As operações para preparação de um kefir de leite, de acordo com a metodologia de Marrshall e Cole (1985) serão descritas abaixo.

$1^{0}$ - Utiliza-se leite integral, depois de fervido, à temperatura ambiente; leite tipo A ou tipo B são recomendados;

20 - Utilizar vasilhame de vidro, se possível de boca larga, nunca use vasilhame ou utensílios de ferro ou inox;

30 - Colocar os grãos, no vasilhame de vidro, junto com leite á temperatura ambiente;

40 - Tampe o vasilhame com um pano;

50 - Entre 24 horas (mais cremosa) e 30 horas (mais firme) formará uma coalhada;

60 - Coar em uma peneira de plástico os grãos;

70 Recoloca-se os grãos, sem lavar, no leite novamente. Irá formar um gel macio e cremoso; não é necessário deixar formar um gel muito duro, a não 
CARNEIRO, C.S. et al. Leites fermentados: histórico, composição, características físicoquímicas, tecnologia de processamento e defeitos. PUBVET, Londrina, V. 6, N. 27, Ed. 214, Art. 1424, 2012.

ser que queira ter um kefir muito fermentado. Nesta operação irá continuar a fermentar e formará uma coalhada parecida com o iogurte;

$8^{\circ}$ Opcionalmente poderá colocar frutas e açúcar a gosto.

Segundo Vale (2009) no preparo desta bebida, basta juntar os grãos de kefir ao leite (da sua preferência) num recipiente e deixar fermentar durante, aproximadamente, 24 horas, à temperatura ambiente. Após este período, deve-se escorrer o leite fermentado para separá-lo dos grãos e o resultado é o kefir pronto para consumir. Os grãos de kefir podem ser utilizados repetidamente para obter mais kefir. Adiciona-se uma parte de grãos de kefir a 15 partes de leite. Ou seja, pode colocar $20 \mathrm{~g}$. (cerca de uma colher de sobremesa) de grãos para aproximadamente $300 \mathrm{~mL}$ de leite e deixe fermentando no tempo, em geral 24 horas e posteriormente passe tudo por uma peneira fina. O líquido resultante é o kefir. Os grãos permanecem na peneira e devem ser devolvidos ao vasilhame lavado para novo preparo. Não é necessário lavar os grãos, mas se julgar necessário, utilize água sem cloro ou o próprio leite do novo preparo.

O mesmo autor relata que há duas espécies de grãos que podem ser utilizadas no preparo do kefir: os grãos frescos ou conservados por dessecação, sendo que os últimos devem ser revitalizados através de um processo longo.

Já para Souza et al. (1984), o preparo consiste em colocar duas ou três colheres de sopa dos grãos em um meio litro de leite e deixar em temperatura de ambiente por 24 horas. Para quantidades maiores ou menores variam-se as proporções. Diferentemente de iogurte, o leite não precisa ser aquecido. Uma vez pronto, coe com um coador de plástico ou peneira, recoloque os grãos em leite fresco para preparar novamente. Este processo é repetido indefinidamente.

De acordo com Dutschaever (1987), para a produção do kefir é necessário acrescentar de 20 a 40 grãos de kefir por litro de leite, em seguida, o recipiente deve ser coberto por um pano que permita a aeração e mantido ao 
CARNEIRO, C.S. et al. Leites fermentados: histórico, composição, características físicoquímicas, tecnologia de processamento e defeitos. PUBVET, Londrina, V. 6, N. 27, Ed. 214, Art. 1424, 2012.

abrigo da luz a uma temperatura de $15^{\circ}$. a $20^{\circ} \mathrm{C}$, a mistura deve ser agitada a cada 3 horas.

Souza et al. (1984) relata que também é possível a preparação de kefir a partir de uma cultura mãe com leite de kefir, sem adição de grãos, iniciando pela preparação da cultura.

Segundo Vecchi (1999) a lactose é consumida e transformada pela cultura que torna o leite enriquecido e assimilável por aqueles que possuem intolerância à lactose. A fermentação do kefir de leite gera um subproduto muito útil, o kefiraride.

O mesmo autor cita um fator muito importante: os grãos de Kefir não devem entrar em contato com quaisquer objetos de metal; porque os grãos de Kefir são ácidos podendo reagir com certos metais; debaixo de certas condições, os metais podem reagir com ácidos produzindo uma corrente elétrica. Isto é o mesmo como uma bateria de carro que produz eletricidade em uma solução ácida.

Em resumo, o kefir pode ser considerado um alimento funcional, pois oferece benefícios à saúde que vão além da nutrição básica, devido a propriedades fisiologicamente ativas de seus componentes alimentícios. O Kefir pode ser considerado um probiótico que é a representação dos alimentos funcionais que tem sido usado para promoção da saúde. Pode ser definido como microrganismos vivos que fermentam os alimentos, promovendo boa saúde por equilibrar a microflora intestinal e também quando esses microrganismos forem ingeridos em determinado número exercem efeitos benéficos à saúde, através dos seus efeitos no trato gastrointestinal, agindo no equilíbrio bacteriano, diminuindo o colesterol plasmático e reduzindo o risco de câncer e diarréias. 
CARNEIRO, C.S. et al. Leites fermentados: histórico, composição, características físicoquímicas, tecnologia de processamento e defeitos. PUBVET, Londrina, V. 6, N. 27, Ed. 214, Art. 1424, 2012.

\subsection{DEFEITOS EM LEITES FERMENTADOS}

Diversos fatores podem contribuir para que o produto final não alcance as características desejáveis. Dentre eles, fatores ligados à matéria prima e contaminações podem ser causas de defeitos em leites fermentados. Além disso, a composição do leite utilizado também influencia diretamente na qualidade do produto. Abaixo estão relacionados alguns defeitos dos leites fermentados de acordo com os autores Lima (2009) e Cerqueira, et al. (1999).

a) Desenvolvimento insuficiente de acidez:

- Leite de vacas sofrendo com mamites pode ser suficientemente anormal de modo que bactérias da fermentação não se desenvolvam normalmente.

- Leite com ocorrência de lipólise como resultado da ação normal de lipases não é um meio satisfatório para culturas láticas porque o maior teor de ácidos graxos livres produzidos é inibitório aos estreptococos. A forma de controle é o uso de leite com atividade normal de lipase ou a pasteurização do leite logo após a produção para inativar as lipases antes da liberação dos ácidos graxos.

- Antimicrobianos: o tempo decorrido para o inóculo iniciar crescimento rápido pode ser tanto que microrganismos indesejáveis tenham se desenvolvido em grande número, ou alterações desejáveis tenham sido retardadas, tornando a qualidade do produto final anormal.

- Bacteriófagos: aparentemente são umas das causas mais importantes da lenta produção de ácido pelas culturas láticas. Quando sua população aumenta, todas as células bacterianas sensíveis são infectadas e usualmente estas são lisadas ou destruídas dentro de 40 a 60 minutos sob condições favoráveis. Quando ocorre lise, a produção de ácido pelas células afetadas estaciona. Portanto uma cultura infectada por bacteriófagos desenvolve acidez normalmente durante os primeiros estágios de desenvolvimento da cultura. Os bacteriófagos podem ser controlados por diversos meios, como rotação de 
CARNEIRO, C.S. et al. Leites fermentados: histórico, composição, características físicoquímicas, tecnologia de processamento e defeitos. PUBVET, Londrina, V. 6, N. 27, Ed. 214, Art. 1424, 2012.

culturas resistentes, sanitização e uso de culturas geneticamente mais resistentes.

- Microrganismos contaminantes: podem reduzir a produção de ácido lático sob certas condições. Algumas espécies de Lactococcus lactis ssp lactis produzem a bacteriocina nisina, que inibe o crescimento e a produção de ácido lático por algumas linhagens de Lactococcos lactis ssp cremoris. O crescimento intenso de Lactococcus lactis ssp lactis no leite, antes da pasteurização pode resultar na produção de suficiente nisina e inibir o crescimento subsequente de uma cultura lática.

- Quaternário de amônia: se estas substâncias estiverem presentes no leite em níveis de, aproximadamente, 5 ppm ou mais, a produção de ácido é menor que a normal. Alguns trabalhos evidenciam que os compostos de quaternário de amônia são mais importantes para retardar a produção de flavor e componentes de aroma que para reduzir a produção de ácido.

b) Defeitos de aparência:

- Sinérese/dessoramento: este defeito se manifesta pela quebra do coágulo e pela presença de soro ao redor e na superfície. As possíveis causas relacionadas a esse defeito são baixo extrato seco, tratamento térmico insuficiente, homogeneização insuficiente, temperatura de incubação muito alta, baixa atividade da cultura, presença de enzimas proteolíticas, distúrbios na agitação durante a acidificação, oxigênio dissolvido no leite e excesso de fermentação.

- Produção de gás: uma cultura gasosa pode ser notada pela presença de bolhas de gás ou por quebra do coágulo resultante da formação de bolhas de gás na superfície. Possivelmente, esse defeito ocorre por falha nas condições de estocagem, contaminação por leveduras e/ou coliformes ou ainda por aeração excessiva da mistura. Em adição a produção de gás, fungos podem desenvolver um flavor de fruta ao leite fermentado. Em decorrência desta produção, a embalagem do produto pode se apresentar estufada. 
CARNEIRO, C.S. et al. Leites fermentados: histórico, composição, características físicoquímicas, tecnologia de processamento e defeitos. PUBVET, Londrina, V. 6, N. 27, Ed. 214, Art. 1424, 2012.

c) Defeitos no corpo e textura:

- Coágulo grumoso: este defeito usualmente esta associado à maturação excessiva, particularmente em altas temperaturas. Algumas vezes o defeito tem sido descrito por contaminação de bactérias, mas acredita-se que não seja causa comum. Outras causas como má dissolução do leite em pó, agitação antes do resfriamento, baixa quantidade de inóculo, desnaturação da albumina e precipitação do fosfato de cálcio podem também levar ao surgimento desse defeito.

- Corpo fraco: frequentemente este defeito esta associado a um leite fermentado de baixa viscosidade, líquido e sem brilho. A baixa viscosidade pode ser causada por baixo conteúdo de sólidos totais, tratamento térmico e homogeneização insuficientes, agitação incorreta, destruição do gel durante a acidificação, tipo de fermento e temperatura de incubação muito baixa. Além disso, o defeito de corpo pode estar geralmente associado à baixa acidez. Este defeito pode ocorrer ainda em leite fermentados elaborados com leite com conteúdo sólido normal. Uma maior consistência desses coágulos pode ser obtida pela adição de 1 a $3 \%$ de leite em pó desnatado ao leite que será usado na produção. Porém, o processo mais usado devido à fabricação em escala industrial é a pré-concentração do leite.

- Viscosidade: a ocorrência de espessamento deve-se a síntese de material capsular (mucinas e galactans) por microrganismos. Os microrganismos implicados são Alcaligenes viscosus, espécies Micrococcus e Lactobacillus delbruecki bulgaricus.

d) Defeitos de sabor e odor:

- Sabor amargo: o gosto é detectado na degustação e pode ser mais pronunciado depois da amostra ser expectorada. Na maioria das vezes pode ser atribuído à presença de proteases termorresistentes elaboradas por bactérias psicrotróficas, na cultura. Algumas bactérias formadoras de esporos, que sobrevivem ao tratamento térmico usual do leite, também podem estar envolvidas. Fatores que possam causar desenvolvimento das culturas láticas 
CARNEIRO, C.S. et al. Leites fermentados: histórico, composição, características físicoquímicas, tecnologia de processamento e defeitos. PUBVET, Londrina, V. 6, N. 27, Ed. 214, Art. 1424, 2012.

inoculadas no leite podem permitir o desenvolvimento dessas bactérias formadoras de esporos e o aparecimento desse defeito na cultura.

- Sabor de levedura: o gosto de levedura sugere um aroma de ácido acético associado ao gosto de ácido. Esse defeito ocorre em virtude da contaminação por leveduras.

- Sabor de malte: ocorre devido a presença de Lactococcus lactis ssp lactis var maltigenes, que age sobre a leucina produzindo 3-metil butanol. Este composto em níveis de $0,5 \mathrm{ppm}$ promove sabor e aroma de malte em leites fermentados, creme e manteiga.

- Insípido: pode ser causado por baixa quantidade de inóculo e baixo tempo de incubação.

- Sabor excessivamente ácido: pode ocorrer por fermentação demasiada, velocidade de resfriamento, temperatura de incubação e estocagem inadequadas.

- Sabor rançoso: deve-se a qualidade do leite cru e em pó.

- Sabor excessivamente doce: uso de açúcar em excesso

\section{CONCLUSÃO}

Vários benefícios à saúde são atribuídos aos leites fermentados. A simples tecnologia de fabricação destes produtos, o elevado prazo de validade e o sabor que agrada, popularizou e difundiu o consumo por todo o mundo. As principais atividades probióticas dos leites fermentados são atribuídas às bactérias ácido-láticas responsáveis pela fermentação do leite e por conferir as características dos diferentes produtos. Alguns defeitos podem ocorrer nos leites fermentados, porém o desenvolvimento insuficiente de acidez parece ser um dos mais sérios, podendo causar sérios prejuízos à indústria de laticínios. Daí a importância do controle de qualidade para o processamento destes alimentos, tanto para que se ofereça um produto aceitável sensorialmente, como para que se obtenha um produto inócuo e que esteja de acordo com às legislações pertinentes. 


\section{REFERÊNCIAS BIBLIOGRÁFICAS}

ADOLFSSON, O; MEYDANI, S.N.; RUSSELL, R.M. Yogurt and gut function. American Journal Clinical Nutrition, v. 80, p. 245-256, 2004.

BRASIL. Ministério da Agricultura, Pecuária e Abastecimento. Instrução Normativa no 46, de 23 de outubro de 2007. Aprova o Regulamento Técnico de Identidade e Qualidade de Leites Fermentados. Brasília, DF, 2007.

CERQUEIRA, M.M.O.P. et al. Leites Fermentados. Belo Horizonte; Monografia da EV-UFMG, 1999.

DUGGAN, C.; GANNON, J.; WALKER, W A. Protective nutrients and functional foods for the gastrointestinal tract. American Journal Clinical Nutrition, v. 75, p. 789-808, 2002.

DUTCOSKY, S. D. Métodos sensoriais em Análise sensorial de alimentos. Champagnat: Curitiba, 1996.

DUTSCHAEVER, C.L.; KEMP, N.; EMMONS, D. Pure culture formation and procedure for the production of Kefir. Milchwiss, v.42, p. 343-345, 1987.

FRENGOVA, G.I. et al. Exopolysaccharides Produced by Lactic Acid Bacteria of Kefir Grains. $Z$. Naturforsch, v. 57, fev-mai, 2002.

HELLER, K.J. Probiotic bacteria in fermented foods: product characteristics and starter organisms. American Journal Clinical Nutrition, v. 73, p. 374-379, 2001.

LIMA, S.C.G. Processamento de leite e derivados. Disponível em: <http://www.eafc-pa.gov.br/ Suely/Leite_e_Derivados.pdf> Acesso em: 04 jul. 2009.

LORETANA, T.; MOSTERTA, J.F.; VILJOEN B.C. Microbial flora associated with South African household kefir. South African Journal of Science, v. 99, n. 1, 2003.

MARSHALL, V.M.; COLE, W.M. Methods for making kefir and fermented milks based on kefir. Journal of Dairy Research, v.52, p. 451-456, 1985.

MONTEIRO, C. L.B. Técnicas de avaliação sensorial. Curitiba, Universidade Federal do Paraná. Centro de Pesquisa e Processamento de Alimentos. 1994.

OLIVEIRA, M. N. et al. Aspectos tecnológicos de alimentos funcionais contendo probióticos. Revista Brasileira de Ciências Farmacêuticas. São Paulo, v.38, n.1, p 1-21, janeiro/março, 2002.

SACCARO, D. M. Efeito da associação de culturas iniciadoras e probióticas na acidificação textura e viabilidade em leite fermentado. São Paulo, 2008. 119f. Dissertação (Mestrado em Tecnologia de Alimentos) - Faculdade de Ciências Farmacêuticas, Universidade de São Paulo, São Paulo, 2008.

SENAI - SERVIÇO NACIONAL DE APRENDIZAGEM. Guia para elaboração do Plano APPCC. SENAI/ DN. Série Qualidade e Segurança Alimentar. Projeto APPCC. SENAI/SEBRAE. Brasília, 1999. 317p. 
SOUZA, G. GARCIA,S. VALLE,J.L.E. Quefir e sua tecnologia - aspectos gerais. Boletim ITAL. Campinas, vol. 21 n2, p.137-155, abril/junho 1984.

TAMIME, A. Y.; ROBINSON, R. K. Yogur. Ciência y Tecnologia. Zaragoza: Acribia, 1991. 398p.

TETRA PAK. Dairy Processing Handbook. Tetra Pak Processing System AB: Lund, Sweden. 1995. 436p.

VALE, P.L.O. Kefir. Disponível em: < http://html.globalshop.pt/cs2646/temas tipos q1id object3D230 q20 q30 q41 q5.htm> Acesso em: 02 jul. 2009.

VECCHI, D.; HAMSANANDA, S.S. Kefir: Uma bênção milagrosa para o nosso século. Disponível em: < http://www.e-familynet.com/phpbb/kefir-uma-beno-milagrosa-para-o--vt145342.html> Acesso em: 02 jul. 2009. 